\title{
Performance Evaluation of $F_{2}$ and $F_{3}$ Progenies in Bitter Gourd (Momordica charantia L) for Qualitative and Quantitative Traits
}

\author{
Y.M. Mahadevprasad ${ }^{1}$, V. Lakshmanan ${ }^{1}$, E.K. Naik ${ }^{2}$ and Jogula Karunakar ${ }^{3}$ \\ Horticultural College and Research Institute, Periyakulam, Tamil Nadu Agricultural \\ University, Tamil Nadu-625 604, India \\ *Corresponding author
}

\section{Keywords}

Bitter gourd, $\mathrm{F}_{2}$ and

$\mathrm{F}_{3}$ progenies,

Evaluation, Mean performance, Yield

\section{Article Info}

Accepted:

24 November 2018

Available Online:

10 December 2018

\section{A B S T R A C T}

An experiment was carried in Horticultural College and Research Institute, Periyakulam, during 2017.The observation were recorded on the following traits, vine length, node at which first female flower appears, days to appearance of first female flower, number of female flowers per vine, days to first fruit harvest, number of fruits per vine, sex ratio, fruit yield per vine, fruit length, average fruit weight, fruit width, fruit cavity, flesh thickness, total soluble solids, protein, ascorbic acid, iron and momordicine content. The highest mean recorded in cross $\mathrm{P} 1 \times \mathrm{P} 5$ ranked the higher order for vine length, node at which first female flower appears, days to appearance of first female flower, number of female flowers per vine, number of fruits per vine, days to first harvest, fruit yield per vine, fruit length, fruit width, average fruit weight, ascorbic acid content, iron, total soluble solids and momordicine content in F2 and F3 generations. The cross $\mathrm{P} 2 \times \mathrm{P} 5$ was the next best which showed desirable per se performance for traits viz., vine length ,days to appearance of first female flower, number of female flowers per vine, number of fruits per vine, fruit length, fruit width, average fruit weight, iron and momordicine content. The cross $\mathrm{P} 3 \times \mathrm{P} 6$, the next best which showed desirable per se performance for traits viz., vine length, node number at which first female flower appears, days to appearance of first female flower, number of fruits per vine, fruit length, fruit width, average fruit weight, and momordicine content. The progenies $\mathrm{P} 1 \times \mathrm{P} 5, \mathrm{P} 2 \times \mathrm{P} 5$ and $\mathrm{P} 3 \times \mathrm{P} 6$ showed the desirable per se performance in F3 generation and also economic traits will be increasing when compared F2 generation and also revealed that high mean was relatively effective in identifying the superior segregants.

\section{Introduction}

Vegetables play an important role in the balanced diet by providing not only energy, but also by supplying vital protective nutrients like minerals, antioxidants, and vitamins. Consumption in sufficient quantity provides all required essential nutrients and a fair amount of fibres. Vegetables also play an important role in neutralizing the acids produced during digestion of proteins and fatty foods, and thus promote digestion and also prevent constipation. Apart from providing nutrition, vegetables provide protect 
against many diseases. Bitter gourd, a member of the cucurbitaceae family, is known as bitter melon, balsam pear and kerala. It grows in tropical areas of the Amazon, East Africa, Asia, India, South America and the Caribbean and is used traditionally both as food and medicine. The genus Momordica includes about 60 species that are native to IndoMyanmar and India is suggested as possible centre of domestication (Sands, 1928). There is a large diversity in bitter gourd for fruit shape (tapering/spindle shaped, elliptical, oblong, long cylindrical, top shaped, and globular), colour (white, milky white, Dark green, light green,) and fruit surface (protuberant and non-protuberant).A compound known as "charatin" present in bitter gourd is used for the treatment diabeties to lower blood sugar levels. The fruit being rich source of vitamin $\mathrm{A}$, vitamin $\mathrm{C}$, iron, phosphorus and carohydrates, is considered as the most nutritive among cucurbits (Miniraj et al., 1993; Desai and Musmade, 1998). It increases body's resistance against pathogenic infections (Beloin et al., 2005). Ironically, this crop has not been exploited to its fullest and still confined to limited areas that too growing with local cultivars only, resulting in low productivity. Major reason behind this low productivity in the lack high yielding varieties and hybrids. Thus, bitter gourd being an important vegetable crop requires a systematic breeding program for enhancement in its yield potential and other horticultural traits. The wild species offer great resource for breeding of cultivated bitter gourd varieties with desirable qualitative traits and tolerance to various biotic and abiotic stresses.

The success of any breeding programme primarily depends on the correct choice of parents. Gilbert (1958) opined that parents with high order of per se performance would be useful in producing better genotypes. Improvement in yield and quality is the main objective at which plant breeder aims, by altering their genetic architecture. Information on nature and magnitude of variability present in the material and association among the various characters is a pre-requisite for any breeding programme. In order to have clear picture of yield components for effective selection programme, there is a need to study for variability in later generation also, as selection pressure can also be applied during these generations. Hence, the study was undertaken with an objective of selecting high yielding progenies of bitter gourd to determine high mean performance and high variation in quantitative characters contributing to yield characters of bitter gourd.

\section{Materials and Methods}

The study was conducted at the Horticultural College and Research Institute, Periyakulam, Tamil Nadu Agricultural University during 2017. The genetic materials were comprised of six progenies viz., $\mathrm{P}_{1} \times \mathrm{P}_{5}$ (MC105 $\times$ Pant karela-2), $\mathrm{P}_{1} \times \mathrm{P}_{6}$ (MC105 $\times$ Arka Harit), $\mathrm{P}_{2} \times \mathrm{P}_{4}$ (TCR471 $\times$ Pusa Do Mousami), $\mathrm{P}_{2} \times \mathrm{P}_{5}$ (TCR471 $\times$ Pant karela-2), $\mathrm{P}_{3} \times \mathrm{P}_{5}$ (BBGS-09$1 \times$ Pant karela-2) and $\mathrm{P}_{3} \times \mathrm{P}_{6}$ (BBGS-09$1 \times$ Arka Harit). The experiment consisted of six bitter gourd progenies sown in randomized complete block design with three replications in $F_{2}$ generation and recommended cultural practices were followed to raise a good crop. Parameters viz. vine length $(\mathrm{cm})$, node at which first female flower appears, days to appearance of first female flower, number of female flowers per vine, days to first fruit harvest, number of fruits per vine, sex ratio, fruit yield per vine ( $\mathrm{Kg}$ per Plant, fruit length $(\mathrm{cm})$, average fruit weight (gram), fruit width $(\mathrm{cm})$, fruit cavity $(\mathrm{cm})$, flesh thickness $(\mathrm{cm})$, total soluble solids (0 Brix) estimated by using hand refractometer, protein (Per cent) estimated by Lowry et al., (1951), ascorbic acid (mg/100g) estimated by A.O.A.C. (1975), iron $(\mathrm{mg} / \mathrm{kg})$ estimated by Lindsay and Norvell (1988) and momordicine content 
(mg/g) suggested by Chandravadana and Subhas Chander (1990) were recorded from thirty randomly selected plants. The selections were made in the $F_{3}$ progeny on the basis of single plant fruit yield. The superior single plants were selected. The seeds from the selfed fruits were collected and stored for further evaluation.

\section{Statistical analysis}

The mean data of all the $F_{2}$ and $F_{3}$ progenies for each character were tabulated and subjected to analysis of variance (Panse and Sukhatme, 1957).

\section{Results and Discussion}

The crosses $\mathrm{P}_{1} \times \mathrm{P}_{5}, \mathrm{P}_{2} \times \mathrm{P}_{5}$ and $\mathrm{P}_{3} \times \mathrm{P}_{6}$ showed the best per se performance for vine length in both $F_{2}$ and $F_{3}$ generations. In general, crosses involving $\mathrm{P}_{1}, \mathrm{P}_{2}$ and $\mathrm{P}_{3}$ as the parents registered high values for vine length, as reported in earlier findings of Kumar et al., (2005), Raja et al., (2007) and Yadav et al., (2008), Tamilselvi (2010) in pumpkin and Karthik Reddy et al., (2013) in ridge gourd. The crosses $\mathrm{P}_{1} \times \mathrm{P}_{5}, \mathrm{P}_{2} \times \mathrm{P}_{5}$ and $\mathrm{P}_{3} \times \mathrm{P}_{6}$ obtained first female flower appearance in early node and less number of days to appearance of first female flower in both the generations. The parents $\mathrm{P}_{1}, \mathrm{P}_{2}, \mathrm{P}_{3}, \mathrm{P}_{5}$ and $\mathrm{P}_{6}$ were found to be better performers for this trait. Similar results were recorded by Thangamani et al., (2011) and Tamilselvi et al., (2015) in pumpkin. Number of female flowers per vine had the highest value in $\mathrm{P}_{1} \times \mathrm{P}_{5}, \mathrm{P}_{2} \times \mathrm{P}_{5}$ and $\mathrm{P}_{3} \times \mathrm{P}_{6}$ in both generations and $\mathrm{P}_{2} \times \mathrm{P}_{4}$ in $\mathrm{F}_{3}$ generation. The highest number of female flowers per vine is due to flower fruit setting percentage, genetic nature, hybrid vigour and adaptability to agro-climatic conditions conforming the report of Thangamani et al., (2011) in bitter gourd, Manikandan (2012) in ash gourd, Bahari et al., (2012) in water melon and Tamilselvi et al., (2015) in pumpkin. The crosses $\mathrm{P}_{1} \times \mathrm{P}_{6}$ and $\mathrm{P}_{3} \times \mathrm{P}_{5}$ in both the generations recorded less sex ratio. The negative sex ratio might be due to varying environmental condition and genetic nature. Similar result was reported by Tamilselvi et al., (2015) in pumpkin and Karthik Reddy et al., (2013) in ridge gourd. The highest fruit length was recorded in $\mathrm{P}_{1} \times \mathrm{P}_{5}, \mathrm{P}_{2} \times \mathrm{P}_{5}$ and $\mathrm{P}_{3} \times \mathrm{P}_{6}$ in $\mathrm{F}_{2}$ and $\mathrm{F}_{3}$ generations. The variation in fruit length was due to the difference in per se performance of parents, genetic nature, vigour of crop and environmental factors. Similar result was reported by Venugopalan and Pitchaimuthu (2009) in watermelon (Table 1-3).

The highest average fruit weight was recorded in $\mathrm{P}_{1} \times \mathrm{P}_{5}, \quad \mathrm{P}_{2} \times \mathrm{P}_{5}$ and $\mathrm{P}_{3} \times \mathrm{P}_{6}$ in both the generations. The highest fruit weight in the cross may due to its hybrid vigour and adaptability to agro-climatic conditions. The present results are in concurrence with the earlier findings of Hanchinamani et al., (2008), Manikandan (2012) in ash gourd, Karthik Reddy et al., (2013) in ridge gourd. The crosses $\mathrm{P}_{2} \times \mathrm{P}_{4}, \mathrm{P}_{2} \times \mathrm{P}_{5}$ and $\mathrm{P}_{3} \times \mathrm{P}_{5}$ in $\mathrm{F}_{2}$ and $\mathrm{F}_{3}$ generations recorded the highest fruit width and fruit cavity. Similar result was reported by Yadav et al., (2008) in cucumber, The highest fruit thickness was recorded in $\mathrm{P}_{2} \times \mathrm{P}_{4}, \mathrm{P}_{3} \times \mathrm{P}_{5}$ in $\mathrm{F}_{2}$ and $\mathrm{P}_{2} \times \mathrm{P}_{5}, \mathrm{P}_{3} \times \mathrm{P}_{6}$ in $\mathrm{F}_{3}$ generation. Similar result was reported by Venugopalan and Pitchaimuthu (2009) in water melon, Manikandan (2012) in ash gourd and Tamilselvi et al., (2015) in pumpkin. The highest ascorbic acid content was recorded in. $\mathrm{P}_{1} \times \mathrm{P}_{5}, \mathrm{P}_{2} \times \mathrm{P}_{4}$ and $\mathrm{P}_{2} \times \mathrm{P}_{5}$. Similar result was recorded by Thangamani et al., (2011) in bitter gourd. The highest total soluble solid was observed in $\mathrm{P}_{1} \times \mathrm{P}_{5}$ and $\mathrm{P}_{2} \times \mathrm{P}_{5}$. Similar result was observed by Bahari et al., (2012) in watermelon. The crosses $\mathrm{P}_{1} \times \mathrm{P}_{5}, \mathrm{P}_{3} \times \mathrm{P}_{5}, \mathrm{P}_{2} \times \mathrm{P}_{4}$ and $\mathrm{P}_{3} \times \mathrm{P}_{6}$ in $\mathrm{F}_{2}$ generation and $\mathrm{P}_{1} \times \mathrm{P}_{5}, \mathrm{P}_{2} \times \mathrm{P}_{4}$ and $\mathrm{P}_{3} \times \mathrm{P}_{5}$ in $\mathrm{F}_{3}$ generation recorded the highest momordicine content. The highest iron content was recorded in. $\mathrm{P}_{1} \times \mathrm{P}_{5}$ and $\mathrm{P}_{2} \times \mathrm{P}_{4}$ in both generations and $\mathrm{P}_{2} \times \mathrm{P}_{5}$ in $\mathrm{F}_{3}$ generation. 
Table.1 Mean performance of $\mathrm{F}_{2}$ and $\mathrm{F}_{3}$ progenies in qualitative and quantitative traits of bitter gourd

\begin{tabular}{|c|c|c|c|c|c|c|c|c|c|c|}
\hline \multirow[t]{2}{*}{ Progenies } & \multicolumn{2}{|c|}{ Vine length(cm) } & \multicolumn{2}{|c|}{$\begin{array}{l}\text { Node at which } \\
\text { first female } \\
\text { flower appear }\end{array}$} & \multicolumn{2}{|c|}{$\begin{array}{l}\text { Days to appear } \\
\text { first female } \\
\text { flower }\end{array}$} & \multicolumn{2}{|c|}{$\begin{array}{c}\text { Number of } \\
\text { female flower per } \\
\text { vine }\end{array}$} & \multicolumn{2}{|c|}{$\begin{array}{c}\text { Days to first fruit } \\
\text { harvest }\end{array}$} \\
\hline & $F_{2}$ & $\mathbf{F}_{3}$ & $\mathbf{F}_{2}$ & $\mathbf{F}_{3}$ & $\mathbf{F}_{2}$ & $\mathbf{F}_{3}$ & $\mathbf{F}_{2}$ & $\mathbf{F}_{3}$ & $\mathbf{F}_{2}$ & $\mathbf{F}_{3}$ \\
\hline $\mathbf{P}_{1} \times \mathbf{P}_{5}$ & $474.2^{*}$ & 533.17 & 18.2 & $16.44^{*}$ & $42.7 *$ & $47.99^{*}$ & $19.4^{*}$ & $17.10^{*}$ & $61.20^{*}$ & $65.92 *$ \\
\hline $\mathbf{P}_{1} \times \mathbf{P}_{6}$ & 303.9 & 408.12 & 20.3 & 18.64 & 55.9 & 51.20 & 15.8 & 13.93 & 71.30 & 68.45 \\
\hline $\mathbf{P}_{2} \times \mathbf{P}_{4}$ & 294.1 & 395.88 & 21.6 & 19.45 & $46.1^{*}$ & 52.84 & 15.9 & $15.11^{*}$ & 65.40 & 70.21 \\
\hline $\mathbf{P}_{2} \times \mathbf{P}_{5}$ & $338.5^{*}$ & 522.32 & 17.5 & 18.15 & 47.5 & 49.55 & 17.3 & $15.18^{*}$ & 66.30 & 68.75 \\
\hline $\mathbf{P}_{3} \times \mathbf{P}_{5}$ & 284.8 & 396.25 & 16.5 & 19.35 & 48.8 & 51.00 & 15.2 & 12.41 & 67.03 & 70.12 \\
\hline $\mathbf{P}_{3} \times \mathbf{P}_{6}$ & 295.9 & 458.96 & 19.1 & $16.76^{*}$ & 47.6 & 49.10 & 17.2 & 14.81 & 66.07 & 69.06 \\
\hline Mean & 331.93 & 452.45 & 18.86 & 18.13 & 48.18 & 50.28 & 17.3 & 14.76 & 66.24 & 68.75 \\
\hline SEd & 8.45 & 6.16 & 1.29 & 0.22 & 0.77 & 0.59 & 0.37 & 0.10 & 0.60 & 0.30 \\
\hline $\begin{array}{l}\text { CD at } \\
(0.05)\end{array}$ & 18.83 & 13.42 & 2.87 & 0.46 & 1.73 & 1.31 & 0.84 & 0.22 & 1.34 & 0.67 \\
\hline
\end{tabular}

*significant at 5 per cent level

Table.2 Mean performance of $\mathrm{F}_{2}$ and $\mathrm{F}_{3}$ progenies in qualitative and quantitative traits of bitter gourd

\begin{tabular}{|c|c|c|c|c|c|c|c|c|c|c|}
\hline \multirow[t]{2}{*}{ Progenies } & \multicolumn{2}{|c|}{ Sex ratio } & \multicolumn{2}{|c|}{$\begin{array}{l}\text { Number of fruit } \\
\text { per vine }\end{array}$} & \multicolumn{2}{|c|}{$\begin{array}{l}\text { Average fruit } \\
\text { weight (g)/vine }\end{array}$} & \multicolumn{2}{|c|}{$\begin{array}{l}\text { Fruit yield } \\
(\text { KG)/vine }\end{array}$} & \multicolumn{2}{|c|}{$\begin{array}{l}\text { Fruit length } \\
\qquad(\mathrm{cm})\end{array}$} \\
\hline & $\mathbf{F}_{2}$ & $\mathbf{F}_{3}$ & $\mathbf{F}_{2}$ & $\mathbf{F}_{3}$ & $\mathbf{F}_{2}$ & $\mathbf{F}_{3}$ & $\mathbf{F}_{2}$ & $\mathbf{F}_{3}$ & $\mathbf{F}_{2}$ & $\mathbf{F}_{3}$ \\
\hline $\mathbf{P}_{1} \times \mathbf{P}_{5}$ & 18.51 & 2.92 & $16.7 *$ & $16.72 *$ & $172.66^{*}$ & $195.10^{*}$ & $2.55^{*}$ & $3.31 *$ & $26.25^{*}$ & $30.15^{*}$ \\
\hline $\mathbf{P}_{1} \times \mathbf{P}_{6}$ & 13.80 & $15.35^{*}$ & 9.70 & 11.57 & 105.80 & 165.30 & 0.95 & 1.84 & 17.12 & 17.64 \\
\hline $\mathbf{P}_{2} \times \mathbf{P}_{4}$ & 17.02 & $16.29^{*}$ & 14.1 & 12.65 & 122.12 & 127.21 & 1.73 & 1.64 & 15.66 & 18.64 \\
\hline $\mathbf{P}_{2} \times \mathbf{P}_{5}$ & 16.25 & 18.08 & 15.2 & 13.45 & $140.51 *$ & $233.07 *$ & $2.11 *$ & $3.11 *$ & $20.15^{*}$ & $31.40^{*}$ \\
\hline $\mathbf{P}_{3} \times \mathbf{P}_{5}$ & 14.26 & $16.53^{*}$ & 13.4 & 11.51 & 110.20 & 113.10 & 1.47 & 1.26 & 15.81 & 17.51 \\
\hline $\mathbf{P}_{3} \times \mathbf{P}_{6}$ & 15.96 & 17.41 & 14.8 & 12.60 & 106.21 & 142.78 & 1.57 & 1.78 & 17.31 & 23.07 \\
\hline Mean & 13.95 & 17.43 & 16.17 & 13.08 & 126.25 & 162.76 & 1.73 & 2.16 & 17.79 & 23.07 \\
\hline SEd & .34 & 0.10 & 0.28 & 0.32 & 0.74 & 2.20 & 0.005 & 0.04 & 0.32 & 0.40 \\
\hline $\begin{array}{l}\text { CD at } \\
(0.05)\end{array}$ & 0.76 & 0.21 & 0.62 & 0.67 & 1.50 & 4.50 & 0.011 & 0.10 & 0.71 & 0.90 \\
\hline
\end{tabular}

*significant at 5 per cent level 
Table.3 Mean performance of $\mathrm{F}_{2}$ and $\mathrm{F}_{3}$ progenies in qualitative and quantitative traits of bitter gourd

\begin{tabular}{|c|c|c|c|c|c|c|c|c|}
\hline \multirow[t]{2}{*}{ Progenies } & \multicolumn{2}{|c|}{$\begin{array}{l}\text { Fruit width } \\
\text { (cm) }\end{array}$} & \multicolumn{2}{|c|}{$\begin{array}{l}\text { Fruit cavity } \\
(\mathrm{cm})\end{array}$} & \multicolumn{2}{|c|}{$\begin{array}{l}\text { Flesh thickness } \\
\text { (cm) }\end{array}$} & \multicolumn{2}{|c|}{$\begin{array}{l}\text { TSS } \\
\left({ }^{0} \text { Brix }\right)\end{array}$} \\
\hline & $\mathbf{F}_{2}$ & $\mathbf{F}_{3}$ & $\mathbf{F}_{2}$ & $\mathbf{F}_{3}$ & $\mathbf{F}_{2}$ & $\mathbf{F}_{3}$ & $\mathbf{F}_{2}$ & $\mathbf{F}_{3}$ \\
\hline $\mathbf{P}_{1} \times \mathbf{P}_{5}$ & 3.45 & 3.68 & 2.28 & 2.42 & 0.51 & 0.63 & $3.28 *$ & $3.05^{*}$ \\
\hline $\mathbf{P}_{1} \times \mathbf{P}_{6}$ & 3.32 & $5.11 *$ & 2.71 & $3.68 *$ & 0.55 & 0.82 & 2.48 & 2.53 \\
\hline $\mathbf{P}_{2} \times \mathbf{P}_{4}$ & $4.15^{*}$ & 4.22 & 2.67 & $3.15^{*}$ & 0.68 & 0.72 & 2.89 & 2.70 \\
\hline $\mathbf{P}_{2} \times \mathbf{P}_{5}$ & $3.96^{*}$ & 4.20 & 2.63 & $2.96^{*}$ & 0.62 & $0.88^{*}$ & $3.21 *$ & $3.13^{*}$ \\
\hline $\mathbf{P}_{3} \times \mathbf{P}_{5}$ & $3.96 *$ & 3.77 & 2.35 & 2.45 & $0.71 *$ & 0.70 & $3.03 *$ & 2.42 \\
\hline $\mathbf{P}_{3} \times \mathbf{P}_{6}$ & 3.08 & 3.73 & 1.82 & 2.54 & 0.67 & $0.85^{*}$ & 2.27 & 2.62 \\
\hline Mean & 3.65 & 4.12 & 2.41 & 2.87 & 0.62 & 0.77 & 2.86 & 2.74 \\
\hline SEd & 0.09 & 0.05 & 0.22 & 0.04 & 0.03 & 0.03 & 0.06 & 0.04 \\
\hline $\begin{array}{l}\text { CD at } \\
(0.05)\end{array}$ & 0.20 & 0.12 & 0.50 & 0.09 & 0.07 & 0.07 & 0.13 & 0.09 \\
\hline
\end{tabular}

*significant 5 per cent level

Table.4 Mean performance of $\mathrm{F}_{2}$ and $\mathrm{F}_{3}$ progenies in qualitative and quantitative traits of bitter gourd

\begin{tabular}{|c|c|c|c|c|c|c|c|c|}
\hline \multirow[t]{2}{*}{ Progenies } & \multicolumn{2}{|c|}{$\begin{array}{l}\text { Protein } \\
(\mathrm{mg} / 100 \mathrm{~g})\end{array}$} & \multicolumn{2}{|c|}{$\begin{array}{l}\text { Ascorbic acid } \\
(\mathrm{mg} / 100 \mathrm{~g})\end{array}$} & \multicolumn{2}{|c|}{$\begin{array}{l}\text { Iron } \\
(\mathrm{mg} / 100 \mathrm{~g})\end{array}$} & \multicolumn{2}{|c|}{$\begin{array}{l}\text { Momordicine } \\
(\mathrm{mg} / 100 \mathrm{~g})\end{array}$} \\
\hline & $\mathbf{F}_{2}$ & $\mathbf{F}_{3}$ & $\mathbf{F}_{2}$ & $\mathbf{F}_{3}$ & $\mathbf{F}_{2}$ & $\mathbf{F}_{3}$ & $\mathbf{F}_{2}$ & $\mathbf{F}_{3}$ \\
\hline $\mathbf{P}_{1} \times \mathbf{P}_{5}$ & 2.16 & $2.18^{*}$ & $102.13 *$ & $100.70 *$ & $2.03 *$ & $1.92 *$ & $2.18 *$ & $2.13^{*}$ \\
\hline $\mathbf{P}_{1} \times \mathbf{P}_{6}$ & 1.55 & 1.71 & 81.02 & 86.20 & 1.50 & 1.69 & 1.55 & 1.74 \\
\hline $\mathbf{P}_{2} \times \mathbf{P}_{4}$ & 1.85 & 1.73 & $100.27 *$ & $100.58 *$ & $1.99 *$ & $1.85^{*}$ & $2.04 *$ & 1.92 \\
\hline $\mathbf{P}_{2} \times \mathbf{P}_{5}$ & 1.80 & 1.80 & $106.8 *$ & $101.60 *$ & 1.70 & 1.79 & $1.96^{*}$ & 1.91 \\
\hline $\mathbf{P}_{3} \times \mathbf{P}_{5}$ & 1.96 & 1.85 & 96.5 & 90.33 & $1.87 *$ & 1.71 & $2.09 *$ & $2.00 *$ \\
\hline $\mathbf{P}_{3} \times \mathbf{P}_{6}$ & 1.95 & 1.78 & 96.07 & $97.83^{*}$ & 1.46 & 1.74 & $2.02 *$ & 1.83 \\
\hline Mean & 1.88 & 1.84 & 97.13 & 96.20 & 1.76 & 1.78 & 1.79 & 1.92 \\
\hline SEd & 0.14 & 0.03 & 1.18 & 0.80 & 0.04 & 0.03 & 0.05 & 0.02 \\
\hline $\begin{array}{l}\text { CD at } \\
(0.05)\end{array}$ & 0.32 & 0.07 & 2.63 & 1.62 & 0.09 & 0.07 & 0.11 & 0.06 \\
\hline
\end{tabular}

*significant 5 per cent level 
The parents showed higher per se value for the above biochemical traits.

In conclusion, in all plant growth character, yield contributing character and qualitative traits, wide range of variations in both crosses of F2 and F3 generation was observed. The progenies $\mathrm{P} 1 \times \mathrm{P} 5 \mathrm{P}_{5}$ (MC105×Pant karela-2), P2 $\times$ P5 (TCR471 $\times$ Pant karela-2) and P3×P6 (BBGS-09-1 $\times$ Arka Harit) showed the desirable performance in F3 generation and also economic traits will be increasing when compared F2 generation. The wide range of variation for yield, plant growth and fruit characteristics in $F_{2}$ and $F_{3}$ generations indicated a scope for selection of desirable plants for crop improvement.

\section{References}

A.O.A.C. 1975. Official methods of analysis. Association of agricultural chemists. Ninetheditior, Washington, D.C.

Bahari, M., M.Y. Rafil, G.B. Saleh and M.A. Latif. 2012. Combining ability analysis in complete diallel cross of watermelon (Citrullus lanatus). Sci. World J. Article ID 543158.

Beloin, N., M. Cbeassor, K. Akpagana, J. Hudson, K. Sousse, K. Koumaglo, and J.T. Amason. 2005. Ethnomodiciflal uses of Momordica charontia (Cucurbitaceee) in Toga and relation to its phytochemistry and biological activity. J. Ethnopharmacol., 96: 49-55.

Chandravadana, M.V and M. Subhas Chander. 1990. Subcellular distribution of momordicine II in bitter gourd (Momordica charantia L.) leaves. Indian J. Exp. Biol., 28:185-186.

Desai, UT., and A.M. Musmade. D.K. Salunkhe and S.S. Kadam (eds.), 1998. Handbook of vegetable science and technology: Production, composition. storage and processing. Marcel Dekker, New York. Pumpkins, squashes and gourds. pp. 273-298.

Hanchinamani CN, Patil MG, Dharmatti PR and Mokashi AN. 2008. Studies on variability in cucumber (C. sativus). Crop Research, 36 (1\&3): 273-276.

Karthik Reddy. P., V. S. K. Reddy and S. S. Vijaya Padma. 2013. Performance of parents and hybrids for yield and yield attributing characters in ridge gourd (Luffa acutangula). The Bioscan, 8(4): 1373-1377.

Kumar, J., D. K. Singh and HariHar Ram. 2005. Determining yield components in pumpkin through correlation and path analysis. Indian J. Hort., 62(4): 346349.

Lindasy, W.L. and W.A. Norvell. 1988. Development of a DTPA soil test for zinc, iron, manganese and copper. Soil Sci. Soc. Amer. J., 42: 421-428.

Lowry, O. H., N. J. Rosen brough, A. L. Farr and R. J. Randall. 1951. Protein measurement with the folin phenol reagent. J. Biol. Chem., 193: 265-275.

Manikandan, M. 2012. Diallel analysis in ash gourd (Benincasa hispida). M.Sc. (Hort.) Thesis submitted to Tamil Nadu Agrl. Univ., Coimbatore, India.

Miniraj, N., K.P. Prasanna, and K.V. Peter, 1993. Bitter gourd Mornordic spp. pp. 239-246. In: C. Kalloo and 8.0. Bergh (ads.), Genetic improvement of vegetable plants. Pergamon Press, Oxford, UK.

Panse, V.G. and Sukhatme, P.V. 1957. Statistical Methods/or Agricultural Workers. 3rd Ed., ICAR, New Delhi, p.381.

Raja S., Bagle B. G. And Dhandar, D. G. 2007. Genetic variability studies in bitter gourd for zero irrigated condition of semiarid ecosystem. Indian J. Hort. 64(4): 425-429.

Tamilselvi, N. A. 2010. Studies on heterosis and combining ability in pumpkin (Cucurbita moschata Duch. ex Poir). 
M.Sc. (Hort.) Thesis submitted to Tamil Nadu Agrl. Univ., Coimbatore, India. Tamilselvi, N. A., P. Jansirani and L. Pugalendhi. 2015. Estimation of heterosis and combining ability for earliness and yield characters in pumpkin (Cucurbita moschata Duch. Ex. Poir). African. J. Agric. Res., 10(16): 1904-1912.

Thangamani, C., L. Pugalendhi, T. Sumathi, C. Kavitha and V. Rajashree. 2011. Estimation of combining ability and heterosis for yield and quality characters in bitter gourd (Momordica charantia L.). Electron. J. Pl. Breed., 2(1): 62-66.

Venugopalan, R. and M. Pitchaimuthu. 2009. Statistical models for stability analysis in watermelon. J. Hort. Sci., 4 (2): 153157.

Yadav M, Singh DB, Chaudhary R and Singh D. 2008. Genetic variability in bittergourd (Momordica charantia L.). Journal of Horticultural Sciences, 3 (1): $35-38$.

\section{How to cite this article:}

Mahadevprasad, Y.M., V. Lakshmanan, E.K. Naik and Jogula Karunakar. 2018. Performance Evaluation of $\mathrm{F}_{2}$ and $\mathrm{F}_{3}$ Progenies in Bitter Gourd (Momordica charantia $\mathrm{L}$ ) for Qualitative and Quantitative Traits. Int.J.Curr.Microbiol.App.Sci. 7(12): 3059-3065. doi: https://doi.org/10.20546/ijcmas.2018.712.350 